\title{
COVID-19: What Went Wrong. Ignoring the Tell-tale Signs!
}

\section{Sara Surani ${ }^{1}$ and Salim Surani ${ }^{2 *}$}

${ }^{1}$ Fulbright Scholar, Harvard College, Cambridge, USA

${ }^{2}$ Adjunct Clinical Professor of Medicine, Texas A\&M University, Texas, USA

*Corresponding Author: Salim Surani, Adjunct Clinical Professor of Medicine, Texas A\&M University, Texas, USA.

The biggest pandemics of all, claiming more than 100 million lives, have long been forgotten. Technology, resources and advancements in research have made people felt they we are invincible. SARS, MERS, Swine flu (H1N1), Ebola and other epidemics have challenged the world [1], but the complacence and delays following public health advice have had immense implications, both on the societal level with high mortality rates, and on a global level with countries' economies crashing. Social consequences of economic and health setbacks have been severe.

The initial spread of this virus in Wuhan Province, China in late December (with a peak in late January), gave the world a good head-start to prepare [2]. This head start, along with a mapping of the viral genome by January 23rd [3], followed by sequencing of messenger RNA against novel corona virus (mRNA-1273) for phase 1 study in 42 days by the Moderna Laboratory in Boston [4], gave the world hope and confidence in their scientific advancement. Examples of countries like China, Singapore and South Korea who have faced the terrors of SARS and Swine flu have moved very rapidly towards quarantine, isolation and social distancing, consequently flattening the curve and also decreasing the Ro. Other nations continued to ignore warnings from public health departments, including the USA. A world leader, esteemed for economic and scientific advancements, ignored the warnings of public health patterns that preceded. Is it a leadership failure of the USA, or is it a failure of numerous leaders across the world who were ignorant of the facts?

A few days before USA declared a State of Emergency, challenges related to COVID-19 were considered a hoax, completely blown out of proportion. Within a matter of days, rather than talking about travel to Moon and Mars, the nation and media were talking about online teaching, handwashing, and social distancing. The public, for the first time, observed the seriousness of the issue, and panicked. This panic resulted in severe shortages of masks and Personal Protective Equipment (PPE) for health care workers worldwide. At the same time, the world woke up and realized that we are living in a pandemic and that COVID-19 is a global issue.

Every country is trying to secure tests for COVID-19, PPE and ventilators. Hospital systems all around the world realized the seriousness of the issue around the same time, resulting in individual and community panic, testing shortages, global economic melt-
Received: March 25, 2020

Published: April 01, 2020

(C) All rights are reserved by Sara Surani and

Salim Surani. downs, global travel shutdowns, and collective chaos. Developed countries have created tremendous stimulus packages, ramping up production work, attempting to cover lost days of production and preparations. Individuals in developing countries, where there is limited infrastructure to respond to a pandemic, started spending more time on their knees praying, rather than in front of the television. It is undeniable that testing shortages in centers in developed and developing countries have led to further spread of the virus, will be more so in countries where public health and health care infrastructure is nearly nonexistent. Unfortunately, the human and economic toll in many developing countries is tremendous and hard to accurately account for. If both developing and developed countries are not accurately and efficiently testing, diagnosing, treating, and counting mortality rates, we may just be seeing the tip of the iceberg.

Over the past week in the United States, cases have been ramping up exponentially, and community spread of virus has been detected in all 50 states. As of 3-23-2020, more than 46,000 cases have been detected with New York, California, and Washington, leading the case toll. Italy implemented social distancing and lockdown late in the curve, resulting in a death toll surpassing that of China: Italy having 778 cases/million, Luxembourg having $1200+$ case/million, compared to China's 56 cases/million [5]. The USA has now initiated a partial lockdown of 75 million people, or almost $25 \%$ of the nation's population. States and counties where incidences are low are still being relaxed in implementing lock downs and aggressive social distancing measures [5].

Hospitals were caught off-guard, as many systems believe that they can get help from their own cities or states. However, one key lesson of pandemics is that when they hit, involve every country and every state worldwide are trying to mobilize and use their stockpiles of medical supplies, PPEs, and ventilators. Nation who have weak health care systems and less than 100 ventilators will have massive casualties when the virus hits them. Currently, some regions have failed to flatten the curve and have overwhelmed health care systems, even of some of the most developed nations including the USA, Italy, Spain and Switzerland. Hospitals are without masks and PPE. Therapies are being tried off label and compassionate basis from chloroquine, hydroxy-chloroquine, Zithromax and Remdesivir, to name a few [6,7]. Furthermore, old therapies like convalescent plasma are being tried as a measure to treat con- 
ditions without any randomized controlled trial. Trials for vaccines and drugs are being undertaken at a fast pace, easing stringent criteria in hope for some cure, but at the same time bringing murky data on safety and efficacy. Nations and their leaders are jumping on studies with less than 50 patients and no clear-cut randomization and/or observational studies are being sold as potential cures [7].

Even if we pass this first wave, are most of our broken health care systems prepared for the second wave of this novel COVID-19? Can the global economy take another financial toll? Would the world be able to survive the implications of another financial collapse? Will there be global increases in unemployment and crime? Is the world too complacent with technology and resources, or is the virus too smart and able to use our strength of social and global travel against us? Who we can blame? The virus, national leaders, personal and community failures in social distancing, or ourselves as nation?

It is still not too late for each one of us to realize our personal, community, and national responsibility. Our actions today will determine what our future will look tomorrow. Let's help flatten the curve. Let us all do our part. Together we are stronger and more resilient than we are individually.

\section{Bibliography}

1. Jarus 0. " 20 of the worst epidemics and pandemics in history" (2020).

2. Timeline: The early days of China's coronavirus outbreaks and cover-up (2020).

3. Rapid data sharing and genomics vital to China virus response (2020).

4. Moderna ships mRNA vaccine against novel corona virus (mRNA-1273) for phase 1 study (2020).

5. Corona virus update live (2020).

6. Al-Tawfiq J., et al. "Remdesivir as a possible therapeutic option for COVID-19". Travel Medicine and Infectious Disease (2020): 101615.

7. Gautret P., et al. "Hydroxychloroquine and azithromycin as a treatment of COVID-19: results of an open- label nonrandomized clinical trial". International Journal of Antimicrobial Agents (2020): 105949.

\section{Assets from publication with us}

- Prompt Acknowledgement after receiving the article

- Thorough Double blinded peer review

- Rapid Publication

- Issue of Publication Certificate

- High visibility of your Published work

Website: https://www.actascientific.com/

Submit Article: https://www.actascientific.com/submission.php

Email us: editor@actascientific.com

Contact us: +919182824667 